一様流中における三次元正四角柱の渦励振および ギャロッピングに及ぼす隅欠き・隅切りの効果

\title{
THE EFFECT OF CORNER-CUTTING OF THREE-DIMENSIONAL SQUARE CYLINDERS ON VORTEX-INDUCED OSCILLATION AND GALLOPING IN UNIFORM FLOW
}

\author{
天野輝 久* \\ Teruhisa AMANO
}

\begin{abstract}
The effect of two kinds of corner-cuttings on vortex-induced oscillation and galloping of three-dimensional square cylinders is investigated in uniform flow. The cross-wind response and vortex shedding frequency are measured on the models with corner-cutting ratios $e / d=0 / 60$ to $20 / 60$, and the mass-damping parameter $\delta \approx 0.20,0.50,0.75$, together with the stationary over-turning moment measurement. As a result, it is found out that although the Strouhal number increases as the increase of coner-cutting ratio resulting in to lower the critical wind speed, the model cutted in right angle with the ratio $e / d=4 / 60$ is most stable, because the vortex-shedding frequency is hardly locking-in until the wind speed becomes $30 \%$ higher than the critical. The Den-Hartog's criterion also suggests the adovantage of this particular type of corner cutting.
\end{abstract}

Keywords : three-dimensional square cylinder, corner-cutting, mass-damping parameter, vortexinduced oscillation, galloping, frequency locking-in 三次元角柱, 隅欠き・隅切り, 質量堿衰パラメータ, 渦动振, ギャロッピング, 周波数ロッキングイン

\section{1. 序論}

我が国初の超高層建築である霞ヶ関ビル (高さ $147 \mathrm{~m}$ ) が 1968 年に竣工して以来, 現在までに, MM21 ランド マークタワー $(296 \mathrm{~m}, 1993$ 年)を筆頭に, 高さ $100 \mathrm{~m}$ 以上の 超高層建築は 220 棟近くを数える. そして最近では，更 に高層の「超々高層建築」のプロジェクトも提案されて いる1).このような高層建築物では主要骨組の大部分が風 荷重で決定される2).そのため, 風荷重の合理的評価が重 要であるばかりでなく, アスペクト比が大きく可撓性に 富み軽量で減衰性にそしい場合には，渦励振やギャロッピ ング等の空力不安定振動の検討が必要となる.

しかし, G.V.Parkinson ${ }^{3)}$ や M.Novak ${ }^{4}$ 等によって確立さ れた準定常的手法によるギャロッピング解析は，共振風 速付近ではその適用が困難である，そのため, 建築物荷 重指針 ${ }^{3}$ では, 石崎他 ${ }^{61}$ ?), 西村他 ${ }^{8}$ 等の研究を参考にし て, 地表面粗度区分や辺長比に応じた発振風速の目安を 与え，それが設計風速を下回る場合には，風洞実験によ り安全性を確認することにしている。

ところで, 構造物の隅角部の形状を変化させて剥離流
を制御することにより空力特性の改善を計る研究が数多 く行われている。

先ず，二次元角柱については E.Naudascher 他”)は角柱 の各面にリブを取り付けたり, ある間隔を隔てて平板を 取り付けるのがギャロッピングの抑制に効果的であるこ とを示した. 白石他 ${ }^{10}$ は隅角部を長さ $e$ だけ直角に欠き 取ったり斜めにカットする（以下，本論文では前者を「隅 欠き」, 後者を「隅切り」と呼ぶ)ことによる空力安定化 を試みた．その結果，隅切りより隅欠きの方が効果的で あり，隅欠きサイズ $e / d=2 / 18 \sim 3 / 18$, 特に, $e / d=2 / 18$ が 後流幅が小さく空力特性に優れ発振風速が高いことを示 した．その後，類似の実験が系統的に行われ，空力特性 や応答が急変するレイノルズ数(ジャンプレイノルズ数) が存在し，角柱の辺長を代表長とするレイノルズ数が $10^{4}$ 以上になるように実験を行う必要性が指摘された ${ }^{11}$. 畑 他 ${ }^{12)}$ は乱強さ $9 \%$ の一様乱流中で, 側面の 2 点間の風圧 差を測定することにより, 文献 (10) と同様, $e / d=5 / 60$ 10/60で変動風圧係数が小さくなることを示した。 
一方，三次元角柱についても数多くの研究が行われて いる. 西村他 ${ }^{13}$ は一様流中で, アスペクト比 4 , 建物密度 $150 \mathrm{~kg} / \mathrm{m}^{3}$, 減衰定数 $1 \%$ の 2 自由度ロッキング模型を用 いた実験により，隅欠きサイズの小さい $e / d=1 / 16$ では， 一旦生じた渦励振がそのままギャロッピングに移行し応 答は不安定であること, $e / d$ が大きいと顕著な渦励振が低 風速で生じることを示した，アスペクト比 4～8, ベき指 数1/4程度の乱流境界層流中での揚力測定 ${ }^{14) \sim 17}$ によれば, 隅欠きや隅切りを施すと迎角に対する揚力勾配が小さく なること, 変動揚力が小さくなりスペクトルのピークが 下ること等が明らかにされている。 また，アスペクト比 4 10, 建物密度 $120 \sim 200 \mathrm{~kg} / \mathrm{m}^{3}$ の乱流境界層流中での

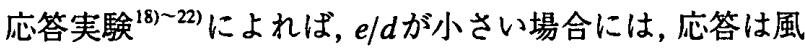
速の増加とともに単調に増加し,$e / d=1 / 20 \sim 1 / 16$ で最も 小さくなること, e/dが大きいと乱流中でも激しい渦励振 が生じること等が明らかにされている.

以上述べたように，珮励振やギャロッピング等の空力 不安定振動を抑制する方法の一つとして隅欠きや隅切り はかなり有効である。しかし，二次元角柱では辺長の $1 / 10$ 程度の隅欠きが最適であるのに対し，三次元角柱では最 適サイズはそれよりやや小さいものと推測されるが，気 流の特性, 辺長比, アスペクト比, 質量隇衰パラメータ の影響など未だ不明な点が多い。

そこで本研究では，高層建築物の不安定振動の解析法 の確立を最終的な目標におき，隅欠きおよび隅切りを有 するアスペクト比 5 の三次元正四角柱を用いて，一様流 中で応答実験㧍よび定常空気力の測定を行い，渦励振や ギャロッピングに及ぼす隅欠き・隅切りサイズゃ質量減 衰パラメータの影瑤を検討した。

\section{2. 実験方法}

実験に使用した風洞は琉球大学工学部のエッフェル型 風洞である。測定断面は $1.0 \mathrm{~m} \times 1.0 \mathrm{~m}$ で床面より数 $\mathrm{cm} の$ 範囲を除いて風速分布は一様で，乱れは $0.5 \%$ 以下と極め
て小さい.

模型は辺長 $d=60 \mathrm{~mm}$, 高さ $H=300 \mathrm{~mm}$, アスペクト此 5 の三次元正四角柱で，図ー 1 に示すように風直角方向 にのみロッキング振動するようにジョイントを介して厚 さ $1 \mathrm{~mm}$, 幅 $60 \mathrm{~mm}$ の板バネで支持した. 板バネは図ー 1 に示す有効長さ $r か ゙ そ れ そ ゙ れ ~ 68,40,30 \mathrm{~mm} \mathrm{の} 3$ 種類を使 用した.ロッキング振動の不動点は板バネの高さの中央 となるので，ジョイント部分を含めた模型の相当高さ $H_{0}$ はそれぞれ $354,340,335 \mathrm{~mm}$ となる.

模型の材料にはウレタン，バルサおよび杉を用いた。 模型は表一 1 に示すように基本断面である「正方形」と， 隅角部を長さeだけ直角に欠いた「隅欠き」と，斜めに カットした「隅切り」の 3 種類である. 正方形模型は材 料および頂部に貼付けた薄板の重量を変えた 10 体であ る. 隅欠き模型と隅切り模型はウレタン (軽量), バルサ (中量) およびバルサ模型の頂部に $40 \mathrm{~g}$ 程度の重りを貼付 けたもの (重量)の3種類である。隅欠き・隅切りサイズ $e / d$ は 0/60〜20/60の 12種類とした.なお, 模型頂部の薄 板の重量を微調整することにより各模型の慣性モーメン トIを一致させて，固有振動数 $f_{0}$ がほほ一定となるよう にした。

本実験では模型の隇衰に特別の制御を加えていない. そこで, $r=68,40,30 \mathrm{~mm}$ の板バネを軽量, 中量, 重量の

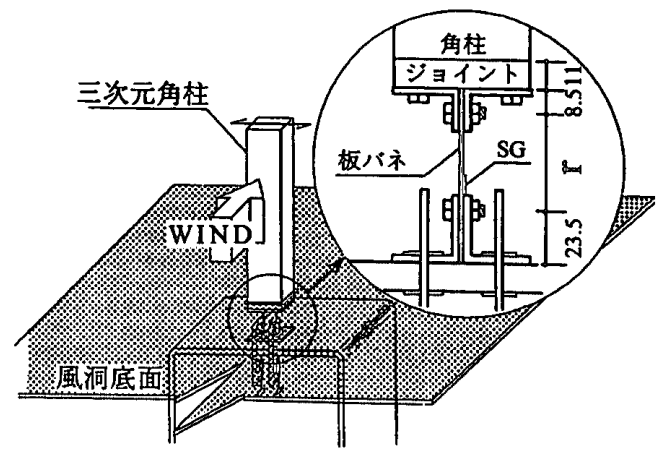

図-1 模型の支持方法

表 -1 模 型 の 種 類

\begin{tabular}{|c|c|c|c|c|c|c|c|c|}
\hline Type & e/d & \begin{tabular}{|l|} 
Num.of \\
Models
\end{tabular} & $\begin{array}{c}r \\
(\mathrm{~mm})\end{array}$ & $H_{0}(\mathrm{~m})$ & $\tilde{\rho_{m}}\left\{=\frac{\tilde{M}}{d^{2} H_{0}}\left(\frac{\mathrm{kg} \cdot \mathrm{s}^{2}}{m^{4}}\right)\right\}$ & $f_{0}(\mathrm{~Hz})$ & $h(\%)$ & $\delta\left(=\frac{\tilde{\rho}_{m}}{\rho} \cdot h\right)$ \\
\hline & $0 / 60$ & 10 & 40 & 0.340 & $1.16 \sim 14.19$ & $6.02 \sim 17.50$ & 1.1 & $0.14 \sim 1.25$ \\
\hline & $0 / 60$ & 12 & 68 & 0.354 & $2.16 \sim 2.38$ & $9.61 \sim 9.80$ & 1.0 & $0.17 \sim 0.19(\approx 0.20)$ \\
\hline & 1 & 12 & 40 & 0.340 & $5.14 \sim 5.82$ & $9.52 \sim 9.84$ & 1.1 & $0.45 \sim 0.51(\approx 0.50)$ \\
\hline (隅久き & $20 / 60$ & 12 & 30 & 0.335 & $7.47 \sim 7.95$ & $8.98 \sim 9.69$ & 1.2 & $0.72 \sim 0.76(\approx 0.75)$ \\
\hline \multirow{3}{*}{$\underbrace{}_{(\text {(晴切り) }} e$} & \multirow{3}{*}{$\begin{array}{c}0 / 60 \\
3 \\
20 / 60\end{array}$} & 12 & 68 & 0.354 & $2.28 \sim 2.38$ & $9.50 \sim 9.80$ & 1.0 & $0.18 \sim 0.19(\approx 0.20)$ \\
\hline & & 12 & 40 & 0.340 & $5.39 \sim 5.82$ & $9.50 \sim 9.88$ & 1.1 & $0.47 \sim 0.51(\approx 0.50)$ \\
\hline & & 12 & 30 & 0.335 & $7.33 \sim 7.79$ & $9.11 \sim 9.69$ & 1.2 & $0.70 \sim 0.75(\approx 0.75)$ \\
\hline
\end{tabular}


各模型に取付け, 減衰定数 $h$ を調べた。図一 2 に平均値 (○) および標準偏差 $($ ト) と模型頂部の振幅 $y$ との関係を 示す. 各模型でそれぞれ $y \approx 5,4,3 \mathrm{~mm}$ 以下で振幅依存性 が認められるが，それ以上の振幅では $h \approx 1.0 ; 1.1,1.2 \%$ と一定である，従って，表一 1 に示すように，各模型の 質量隇衰パラメータ $\delta\left\{=\left(\tilde{\rho}_{m} / \rho\right) h\right\}$ は $0.20,0.50,0.75$ の 三種類となる。ここに $\tilde{\rho}_{m}\left\{=\tilde{M} / d^{2} H_{0} ; \tilde{M}=I / H_{0}{ }^{2}\right\}$ は一般 化密度であり, $\rho$ は空気密度である. 因に, $\delta \approx 0.50$ は建 物密度 $180 \mathrm{~kg} / \mathrm{m}^{3}$, 減衰定数 $1 \%$ 程度の一般的な高層建築 物 ${ }^{23)}$ に相当する.

角柱頂部の振幅 $y$ を板バネに貼付した歪ゲージにより 測定し, シグナルプロセッサ(7T08S, 日本電気三栄)によ り標準偏差 $\sigma_{y}$ を求めた. 平均風速 $U$ はピト一管により測 定し, 渦発生周波数 $f_{v}$ は角柱の中心から風方向に $2 d$, 風 直角方向に $1.5 d$ の位置で熱線風速計 (8100, KANOMAX) で測定した変動風速のパワースペクトルのピーク周波数 から求めた.

一方, 定常空気力の測定は図ー3に示すように模型を 5 分力計 (LMC-5510-5, 日章電機) に固定し, 図-4に示し た角柱底面での建物軸方向の転倒モーメント $M_{X}, M_{Y}, Y$ 方 向の変動転倒モーメント $M_{Y_{m}}$ を風向角 $\alpha$ を変えて測定し た. 各空気力係数の定義を図中に示す.

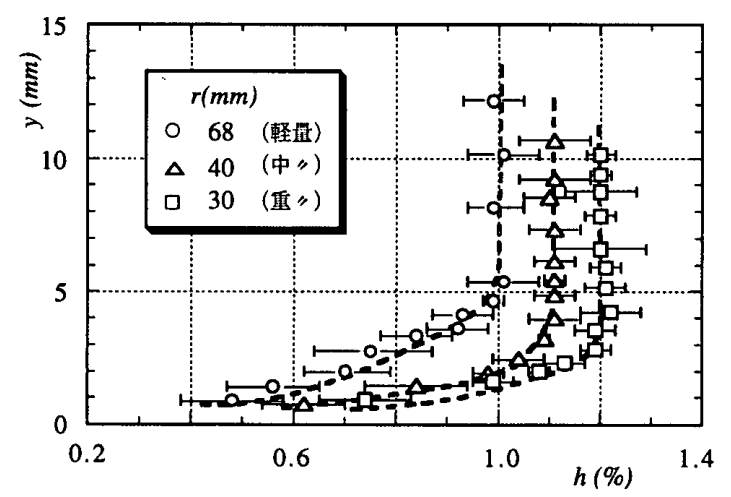

図-2 各模型の減衰定数
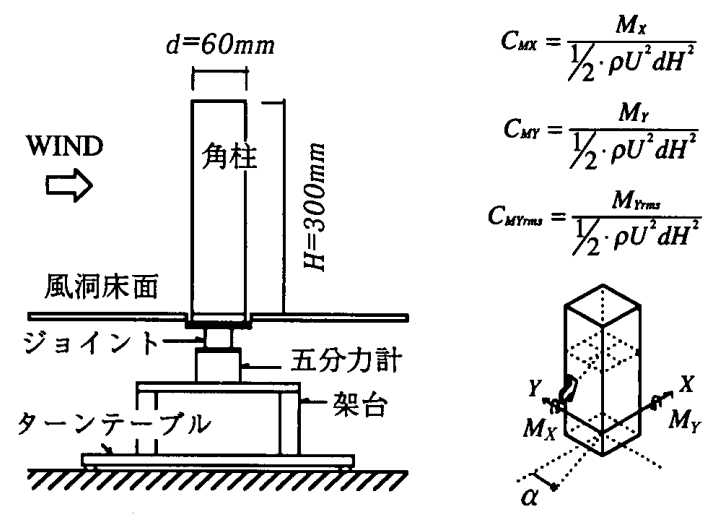

図-3 定常空気力の測定方法

\section{3. 角柱の応答}

\section{1 正四角柱の応答}

正四角柱の応答と渦発生周波数 $f_{v}$ の一例 $(\delta \approx 0.70)$ を図 -5に示す. 横軸は無次元風速 $V\left(=U / f_{0} d\right)$ であり，応答は 標準偏差 $\sigma_{y}$ を角柱の相当高さ $H_{0}$ で除した無次元振幅 $\sigma_{y} / H_{0}$ で表わした，風速を上げた場合 (O印)，応答は $V \approx 8$ から大きくなり, 共振風速 $V^{*}=9.1(=1 / S, S$ ：ス卜 ローハル数)を越えても增大し続け，V=13で急激に小さ くなる，逆に，風速を下げた場合(๑印)は， $V \approx 13$ になっ ても小さいままで $V \approx 11$ で急激に增大し，それ以降は風 速を上げた場合と同じ経路をたどる。このように角柱の 応答にはヒステリシスが認められ自励的渦励振の様相を 呈する. $f_{v}$ は風速が小さい範囲では風速に比例するが, $V \approx 0.8 V^{*}$ から固有振動数成分が現われ, 周波数ロッキン グインが応答の顕著な $V \approx 13$ まで続く.

図一6は $\sigma_{y} / H_{0}$ が $5 / 1000$ および $1 / 100$ を越える風速（以 下, 限界風速と呼ぶ) の範囲を示す. $\delta \approx 0.5$ 以下では限界 風速を越えると渦励振がそのままギャロッピングに移行

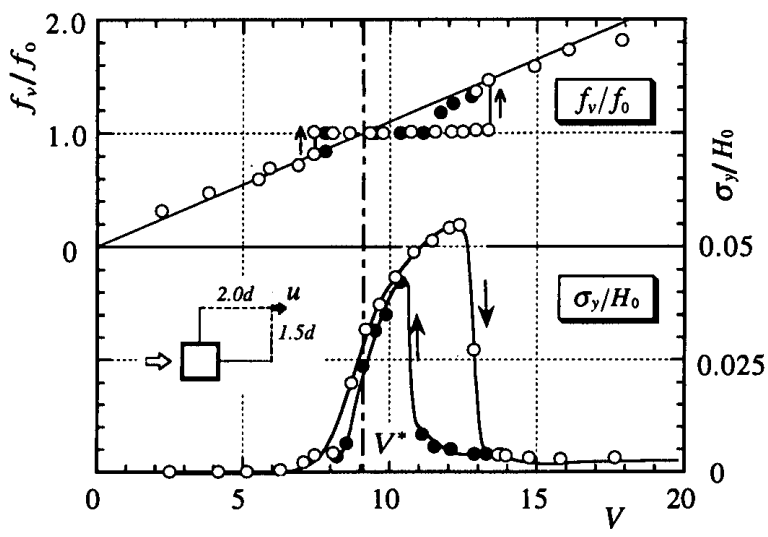

図-5 正四角柱の応答と渦発生周波数 $(\delta \approx 0.70)$

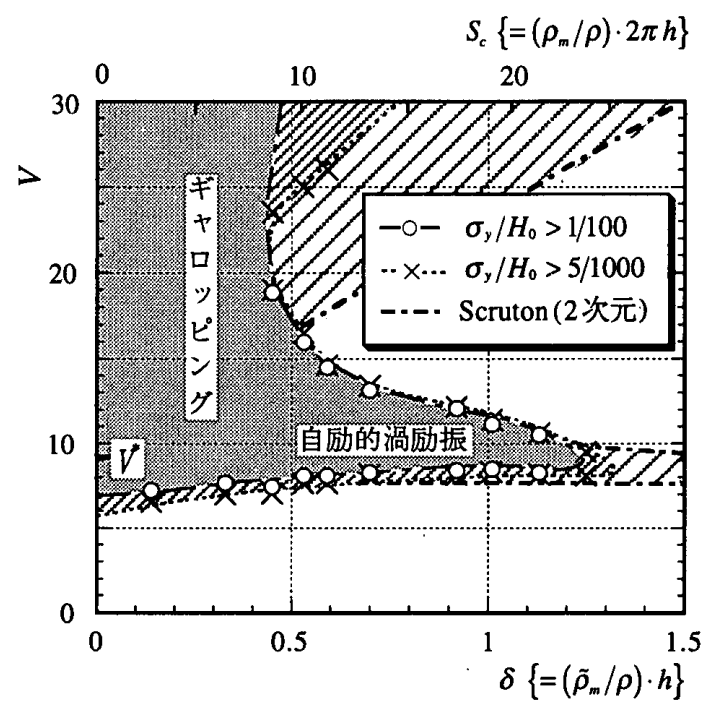

図 -6 空力不安定領域（正四角柱） 


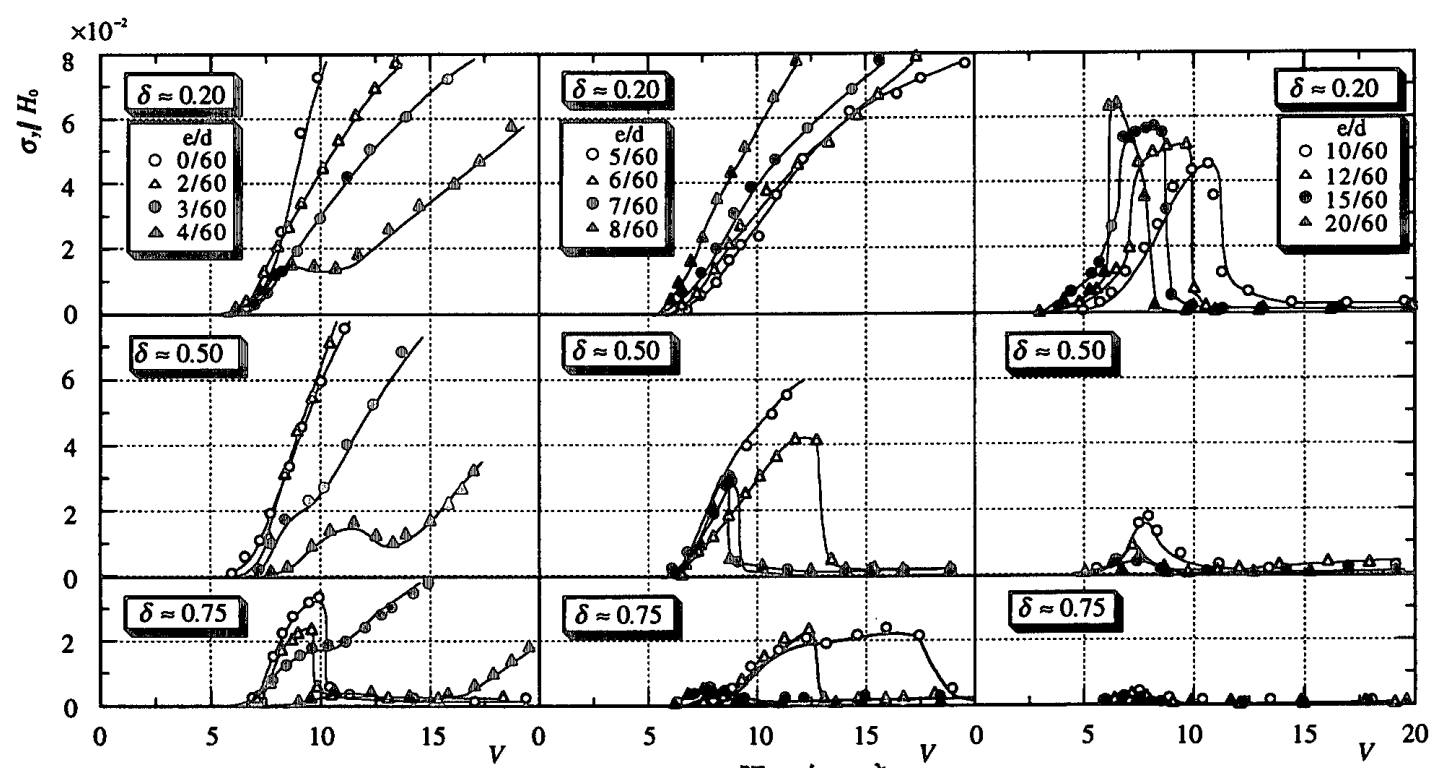

(a) 隅 欠 き

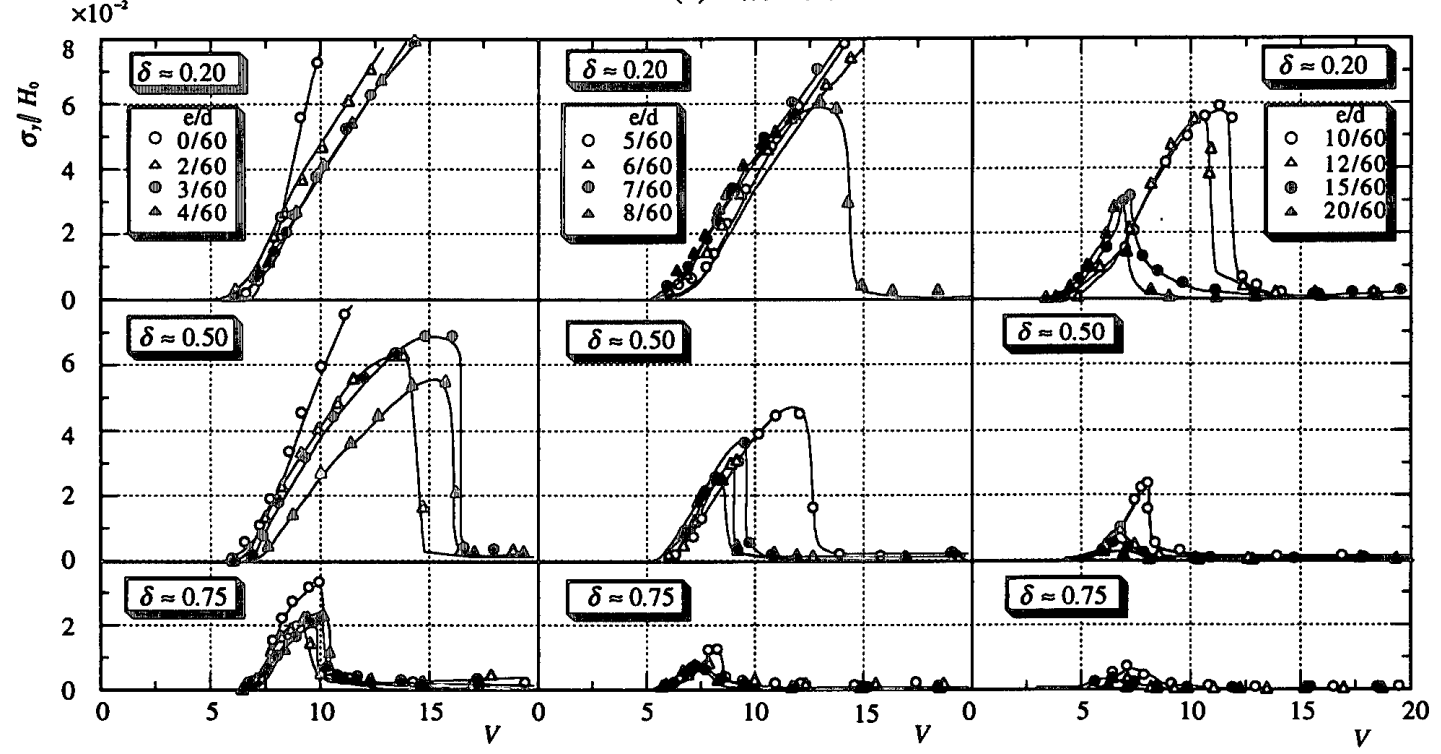

(b) 隅 切 り

図一7 無次元風速と応答振幅の関係

するが， $\delta \approx 0.5$ 以上では自励的渦励振のみが生じる.この ように三次元角柱では,スクルートン数 $S_{c}\left\{=\left(\rho_{m} / \rho\right) \cdot 2 \pi h\right\}$ が10以上の二次元角柱 ${ }^{24)}$ で見られるギャロッピングに起 因する不安定領域は認められない。

3.2 隅欠き・隅切りを有する正四角柱の応答

隅欠きおよび隅切りを有する正四角柱の無次元風速 $V$ と無次元振幅 $\sigma_{y} / H_{0}$ の関係を図一 7 に示す.

先ず，(a)の隅欠きの場合， $\delta \approx 0.20$ の $e / d=0 / 60 \sim$ $8 / 60, \delta \approx 0.50$ の $e / d=0 / 60 \sim 5 / 60$ のように, $\delta$ 小さいか $e / d$ が小い場合には, $V=6$ 7から応答が急激に増加す るギャロッピングが生じる．応答の大きさは $e / d=4 / 60$

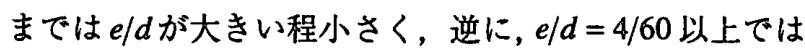
$e / d$ が增えると增大する. $e / d=3 / 60$ と $4 / 60$ は他と異なっ
て，渦励振がやや収まりかけた後にギャロッピングに移 行する複合型となっている. $e / d=4 / 60$ は応答が大きくな り始める風速(発振風速) が最も高く, $1 / 10 か ゙$ 最適である 二次元角柱 ${ }^{10,12)}$ と違って, 三次元角柱では $4 / 60$,すなわち $1 / 15$ が最適であることを示している。一方, $\delta \approx 0.20$ の $e / d \geq 10 / 60, \delta \approx 0.50$ の $e / d \geq 6 / 60$ では, 特定の風速で応 答が大きくなる自励的渦励振が生じている. そして, e/d が大きいほど発振風速が低い。

一方, (b)の隅切りは $\delta \approx 0.20$ の $e / d=0 / 60 \sim 7 / 60$ でギャ ロッピングが生じており, それ以外は渦励振型である. 隅欠きで見られた複合型の応答は認められない，最適な 隅切りサイズは隅欠きと同じく, 発振風速が最も高い $e / d=4 / 60$ である. 


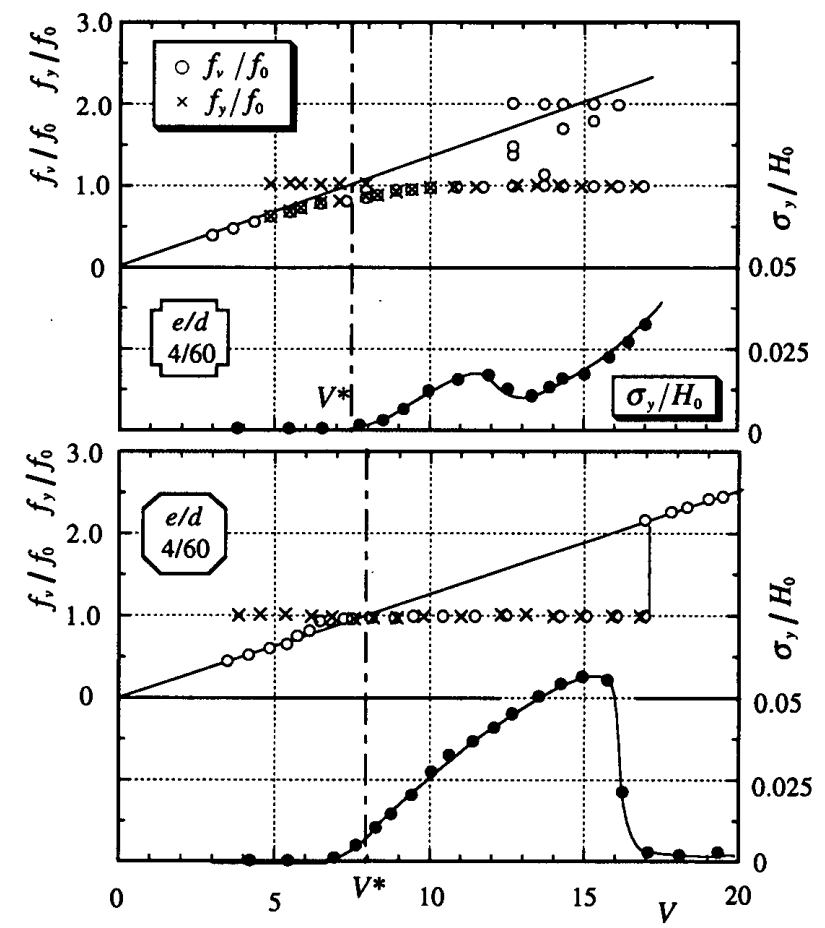

図 -8 応答と渦発生周波数 $(e / d=4 / 60, \delta \approx 0.50)$

応答抑制に最適であった隅欠き・隅切りサイズ $e / d=4 / 60$ について, 後流中の渦発生周波数 $f_{v}$ (大印)およ び角柱の応答周波数 $f_{y}(\times$ 印 $)$ と $V$ との関係を $\delta \approx 0.50$ の 場合について図－8に示す．図中には応答結果も示して あリ，隅欠きと隅切りとを比べると隅欠きの方が応答が かなり小さい. 隅切りの場合，正四角柱(図－5) と同じ ように, $V^{*}(=7.9) の 8$ 割程度の風速から渦励振の収まる $V \approx 17$ まで, $f_{v}$ が角柱の運動に引き込まれる周波数ロキン グインが続く．これに対して，隅欠きでは低風速でVに 比例して増加する $f_{v}$ が, $V^{*}$ の7割程度の $V \approx 5$ から比例関 係を下まわりながら $f_{0}$ に漸近する特異な形をとり，V*の 約 1.3 倍の $V \approx 10$ になって始めて $f_{0}$ に一致する，そして， 角柱の応答周波数にも $f_{v}$ と同じ成分が認められる。この ように，隅欠きの $e / d=4 / 60$ が空力的に最も安定してい るのは, 共振風速を越えるかなりの高風速まで渦発生周 波数が角柱の固有振動数に一致しないためである。

図ー9にその他の隅欠きおよび隅切りサイズについて $f_{v}$ と $V$ の関係を示した． 斜線部は $f_{v}$ が $f_{0}$ に一致する領域 を示し，一点鎖線は共振風速を示す．隅欠き・隅切りと も $e / d=4 / 60$ までは, $e / d$ の増加とともに共振風速が低下 するにも拘わらず $f_{v} \approx f_{0}$ となる風速は高くなり，それ以 上では逆に低くなっている，そして，隅欠きの $e / d=4 / 60$ だけが共振風速を大きく越えた風速まで $f_{v}$ が $f_{0}$ に一致し ない.

図－10に $\sigma_{y} / H_{0}$ が $1 / 100$ を越える空力不安定領域を示 す. 隅欠き・隅切りとも, $e / d=0 / 60 \sim 4 / 60$ では $e / d$ 増加
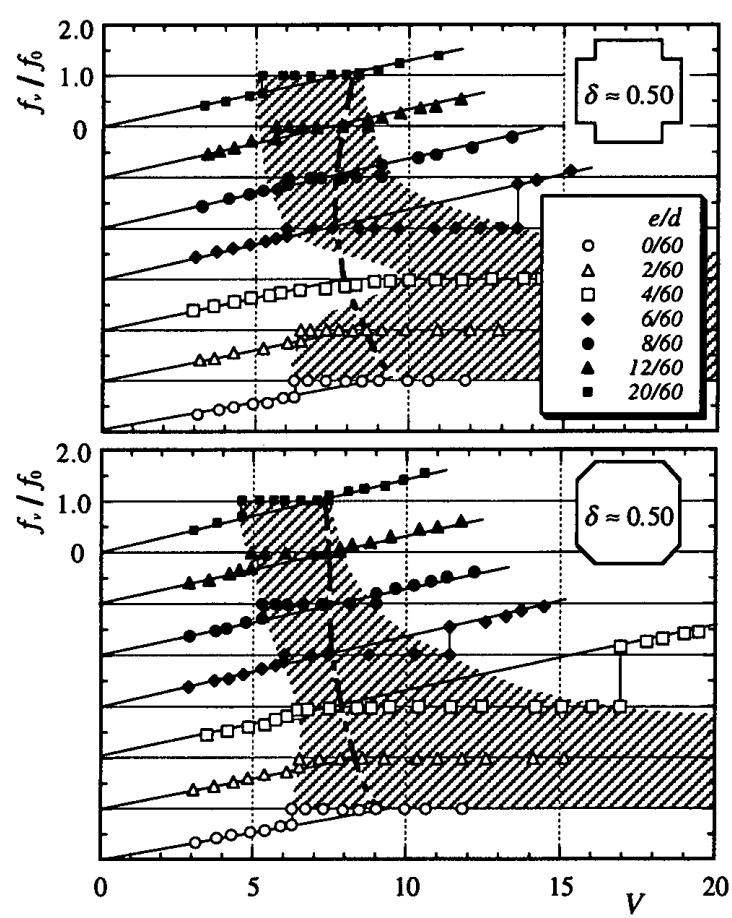

図－9 周波数ロッキングイン領域
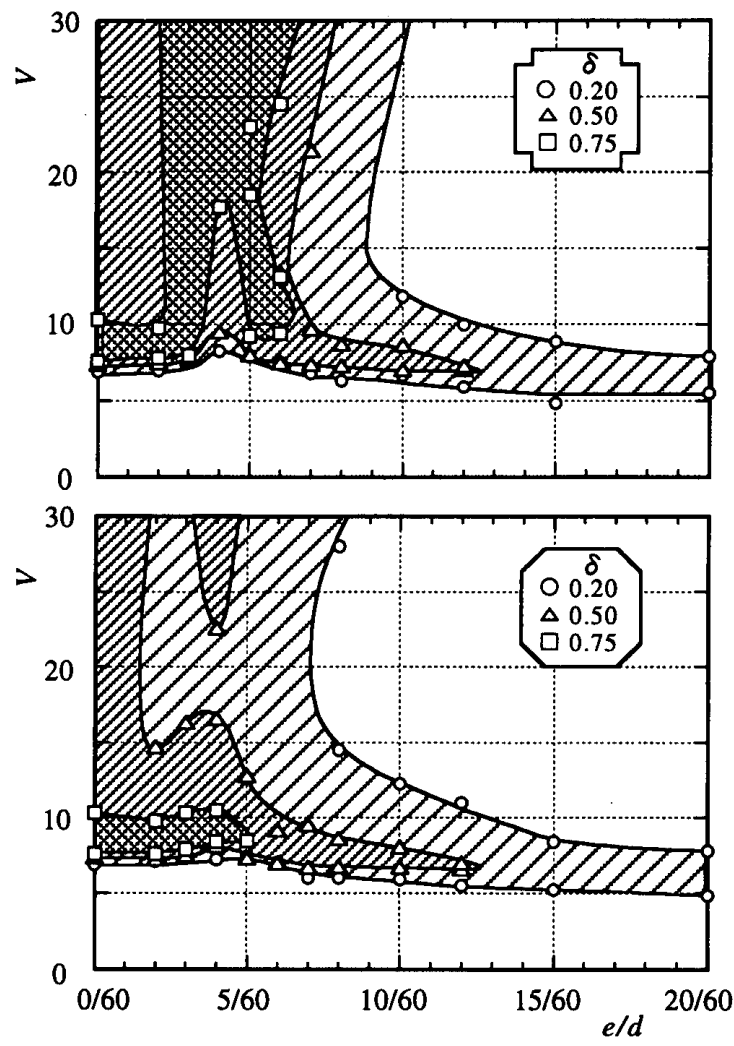

図 - 10 空力不安定領域 $\left(\sigma_{y} / H_{0} \geq 1 / 100\right)$

とともに限界風速は徐々に高くなる.それ以上では $e / d の$ 増加とともに低くなり，隅欠き・隅切りサイズの大きい ものでは正方形断面よりも低くなっている，いずれの $\boldsymbol{\delta}$ においても $e / d=4 / 60$ の限界風速が最も高く, 特に, 隅欠 きの $\delta \approx 0.75$ は $V \approx 18$ と極めて高くなっている.不安定領 


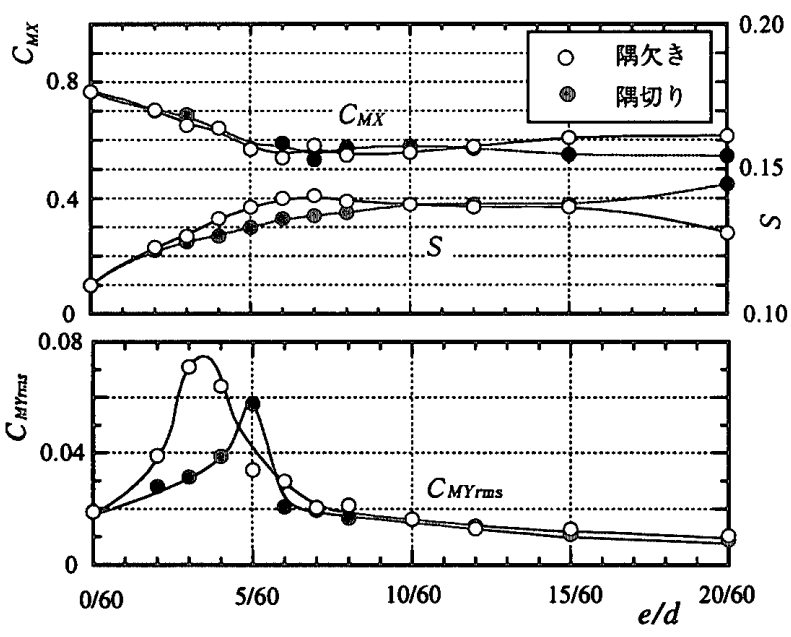

図－11 定常空気力に及ぽす $e / d$ 影響 $\left(\alpha=0^{\circ}\right)$

域にはギャロッピングと渦励振とにそれぞれ起因する領 域があり，その境界が例えば隅欠きの $\delta \approx 0.50$ では $e / d=6 / 60 \sim 7 / 60$ となっている。このような不安定領域 ( $V-e / d$ 図)は, 図一 6 に示した正方形断面の不安定領域 ( $V-\delta$ 図)と似ており,e/dがあまり大きくない限り,e/d を増すことと $\delta$ 増すことは同じ効果があることが判る。

\section{4. 定常空気力}

図－11に隅欠き・隅切りを有する三次元角柱の風向角 $\alpha=0^{\circ}$ における風方向の転倒モーメント係数 $C_{M X}$, 風直角 方向の変動転倒モーメント係数 $C_{M Y r m s}$ およびストローハル 数 $S$ と $e / d$ との関係を示す. 隅欠きと隅切りとで $C_{M x}$ は概 ね同様の傾向を示す. 正四角柱では $C_{M X}$ は 0.8 程度である が，隅欠き，隅切りを施すと, $e / d=6 / 60$ でその約 7 割に 低下する.しかし,$e / d=6 / 60$ 以上では $e / d$ を増しても $C_{M X}$ は殆ど変化せず, 再び増加する二次元角柱 ${ }^{10)}$ とは異なっ ている，ストローハル数 $S$ も隅欠きと隅切りはほほ同様

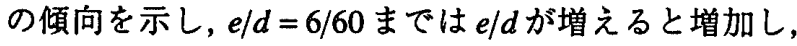
$C_{M X}$ の変化とは逆になっている.

次に，隅欠き・隅切りのない場合の $C_{M Y M s}$ は $0.02 て ゙, 二$ 次元角柱の変動揚力係数 ${ }^{12)} に$ 比べて極めて小さい. そし て, 隅欠きで $e / d=2 / 60 \sim 4 / 60$, 隅切りで $e / d=4 / 60 \sim 5 / 60$ でその2〜3倍と大きくなるが, $e / d$ 増加とともに再び小 さくなる. $C_{M Y m s}$ が $e / d \approx 4 / 60$ で大きくなるのは，図一 12 に示すパワースペクトル密度から分かるように，低周波 領域に大きなパワーがあり, 渦発生がかなり不安定であ るためである。

図－13 は風直角方向の転倒モーメント係数 $C_{M Y}$ と $\alpha$ と の関係を表わしたものである，隅欠きを施すと剥離せん 断層が角柱側面に近づくために， $C_{M Y}$ が最小となる風向角 は隅欠きのない場合に比べて小さくなる．最も小さいの は $e / d=3 / 60 \sim 4 / 60$ で約 $10^{\circ}$ である. $e / d$ を増すとこの風向

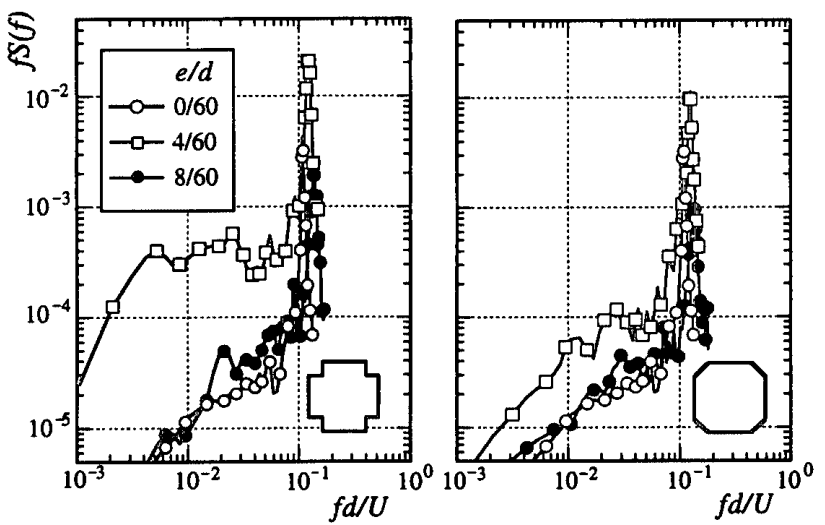

図ー 12 変動転倒モーメンのパワースペクトル密度
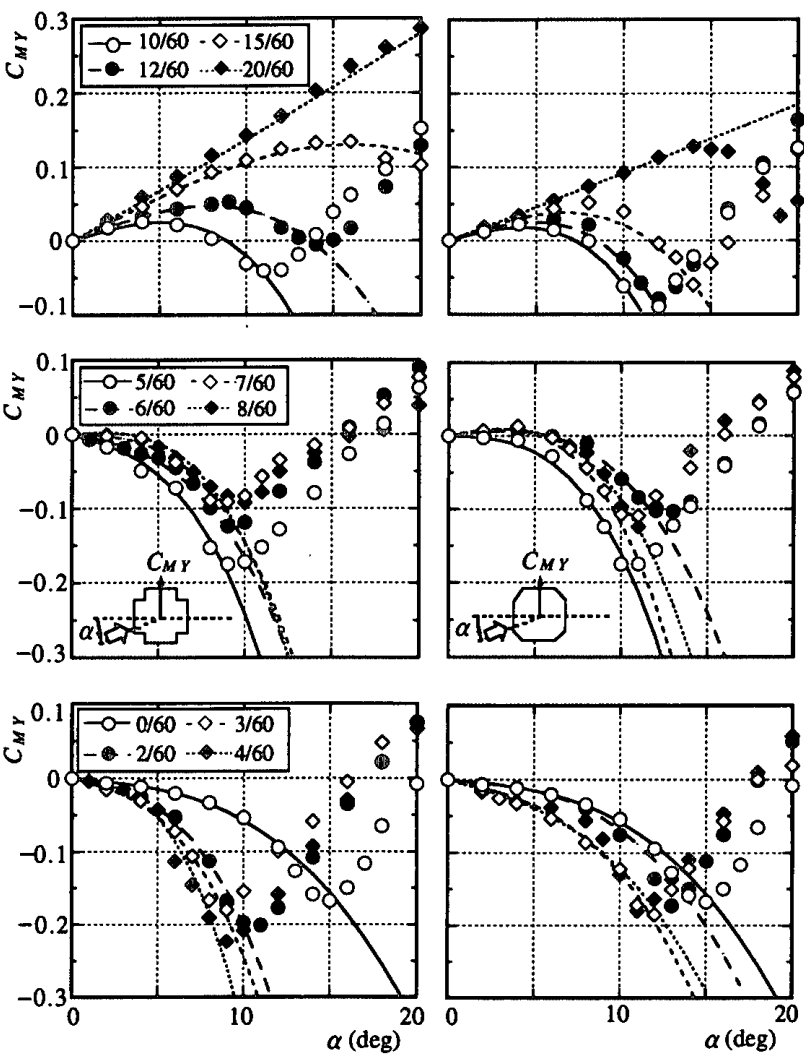

図-13 $C_{M Y}$ と風向角 $\alpha$ の関係

角は再び大きくなる. そして, $e / d=10 / 60$ 以上では $C_{M r}$

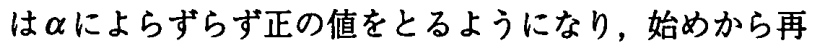
付着型となっている.なお, 隅切りの $C_{M Y}$ も全体的にほほ 同様の傾向を示す.

図一 13 の各曲線は $\alpha \approx 0^{\circ}$ 付近が最も適合するように， $C_{M Y}$ と $\alpha$ の関係を一次と三次の係数を持つ多項式で近似

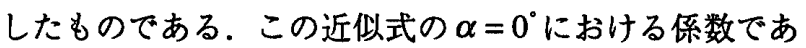
る Den Hartog の判別式 ${ }^{24)}$ を表わしたのが図ー 14 である. 隅欠きでは $e / d=7 / 60$ 以下で負となり不安定となるが, $e / d=4 / 60$ は不安定度がやや小さい，隅切りでは $e / d=5 / 60$ 以下で負となる. 


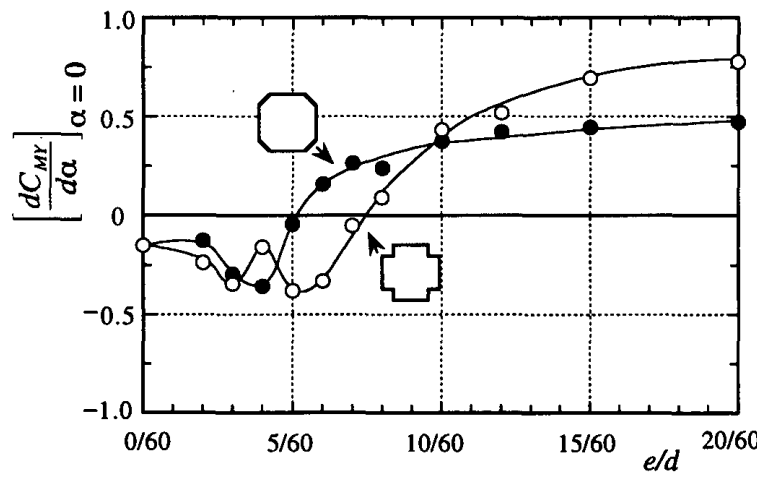

図ー 14 Den Hartog の判別式と e/dの関係

\section{5. 結論}

本研究は三次元角柱の渦励振やギャロッピング等の空 力不安定振動に及ぽす隅欠き・隅切りの効果を明らかに するために, 3種類の質量隇衰パラメータを有する模型を 用いて，一様流中で応答実験および定常空気力の測定を 行った。本研究により明らかになった事項を列記すれば 以下の通りである。

1）隅切りより隅欠きの方が空力安定効果は大きい.

2）空力不安定振動を抑制するための最適な隅欠きサイズ $e / d$ は, 周波数ロッキングインが特異な形をとり, 渦 発生周波数が共振風速の約 1.3 倍の風速まで固有振動 数に一致しない $4 / 60$ ，すなわち $1 / 15$ である.

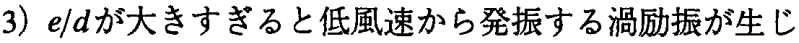
るので不適切である。

4) 応答パターンを特徴づける正四角柱の空力不安定領域 ( $V-\delta$ 図)と，隅欠き・隅切りを有する四角柱の不安 定領域 $(V-e / d$ 図 ) は形状が似ており, e/dがあまり大 きくない限り,$e / d$ を增すことは質量減衰パラメータを 増すことと類似の効果をもたらす。

4) 風直角方向の変動転倒モーメント係数は, 正四角柱で は0.02程度だが, $e / d \approx 3 / 60 \sim 5 / 60$ では低周波領域での 不安定な変動に起因してその 2 3 倍となる。

5）Den Hartog の判別式によれば，隅欠きで $e / d=7 / 60$, 隅切りで $e / d=5 / 60$ 以下で負となる.

今後, 乱琉中での隅欠き・隅切りの効果を明らかにす るとともに, 空力不安定振動を含む風直角方向応答の解 析手法の開発が必要と思われる。

\section{〈謝 辞〉}

本研究を行うに当たり御指導頂いた神奈川大学教授大熊武司 先生，東京工業大学教授和田章先生に深く感謝申し上げます. また，実験を行うに際し，琉球大学卒論生，花城克尚君，宮城 哲矢君, 酒瀬川政友君, 福島弘志君, 加藤英五君および修論生, 水田和宏君に多大の協力を頂いた。

\section{《参考文献〉}

1）近藤宏二，“風と超高層”, 建築技術，pp.123-125, 1994.7

2）大熊武司, “風と建築一室戸台風から横浜ランドマークタワーまで”, 建築技術，pp.60-67, 1994.7

3) Parkinson,G.V., "Aeroelastic Galloping in one Degree of Freedom", Proc.Int. Conf.on Wind Effects on Buildings and Structure (Teddington), Her Majesty's Stationary Office, pp. 582-609, 1963

4) Novak,M., "Galloping Oscillation of Prizmatic Structures", Proc. ASCE, Vol. 98, EM1, pp.27-46, 1972.2

5）日本建築学会，“建築物荷重指針 ·同解説”, pp.273-279, 1993.6

6）石崎湀雄，谷池義人，“風向直角方向に振動する角柱の空力不安定 性について”，日本建築学会論文報告集，第306号，pp.11-19, 1981.8

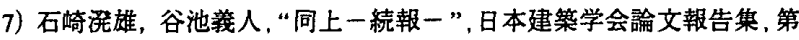
307 号, pp.24-33, 1981.9

8）西村宏昭, 谷池義人，“境界層流中に打ける高層建物の空力不安定振 動，正方形断面をもつ高層建物の場合”，日本建築学会構造系論文 集，第 456号，pp.31-37, 1994.2

9) Naudascher, E.,Weske,J.R. and Fey,B., "Exploratory Study on Damping of Galloping Vibrations ", J. Wind Eng. and Ind. Aero,Vol. 8, pp.211222,1981

10）白石成人，松本 勝他，“隅切りによる矩形断面の空力安定奻果”, 風工学シンポジウム，pp.193-198, 1986

11）白土博通，松本 勝、“隅切り断面の空力諸特性に及ほすレイノル 艾数効果”, 日本風工学会誌, 第 59 号, pp.5-9, 1994.5

12）烟健太郎, 神田 順他, “風圧の諸特性に対する隅切りの効果”, 日 本建築学会大会学術講演梗概集、構造 I，pp.1065-1066，1993.9

13）西村宏昭, 谷池義人,“高層建物の隅角部形状が振動に及は寸影響 について”，日本建築学会大会学術講演梗概集，pp.123-124, 1989.10

14）林田英俊，岩佐義辉，又不義浩，“超々高層建物の渦励振に関する 空力的形状効果”, 日本建築学会大会学術講演梗概集（関東）,pp.141$142,1988.10$

15）上森康幹，崔 恒，神田 順，“風直角方向における变動風力の統 計的特性”, 日本建䓩学会大会学術講演梗概集 (九州)，pp.117-118, 1989.10

16）拣見 豊、“高層建物の風振動に関する風洞実験その 1 矩型建物の 隅切り効果について”, 日本建築学会大会学術講演梗概集 (九州) pp.125-126, 1989.10

17）山本浩二, 中山昌尚他, “超高層建物の風応答に及ほす隅切り効果”, 日本建築学会大会学術講演梗概集 (中国)，pp.113-114，1990.10

18) Kwok,K.S.C. and Bailey, P.A., "Aerodynamic Devices for Tall Buildings and Structures, J. Eng. Mech., ASCE, Vol. 113, pp.349-365, 1987

19）西村宏昭，谷池義人，“高層建物の隅角部形状が振動に及ほ寸影響 について，その2：境界層乱流中の応答特性”，日本建築学会大会 学術講演梗概集, pp.115-116, 1990.10

20）大熊武司，丸川比佐夫他，“隅欠きとバルコニーを有する超高層建 物の風洞実験，その 2-镸動性状”, 日本建筑学会大会学術講演梗概 集, pp.1097-1098, 1993.9

21）松井正宏，日比一晋他，“基本角柱の空気力低减方法に関寸る実験 的研究”，日本建棐学会大会学術講演梗概集，pp.175-176, 1994.9

22）高口 真, 河井宏九。“超高層建築物の風による振動の低減”, 日本 建等学会大会学術講演梗概集，pp.181-182, 1994.9

23) Scruton,C. and Flint,A.R.,"Wind-excited Oscillations of Structures, Proc. of the Institution of Civil Engineers, Vol.27, pp.673-702, April, 1964

24）日本建案学会，“建築物荷重指針・同解説”, pp.254-255, 1970

（1995年 5 月 10 日原稿受理， 1995 年 8 月 23 日採用決定） 